\title{
IRON AGE CEMETERIES AND HIISI SITES: IS THERE A CONNECTION?
}

\author{
Anna Wessman
}

\begin{abstract}
This article discusses the Finnish hiisi sites which were listed in the 1967 doctoral thesis of the linguist Mauno Koski. Based on place names, Koski associated 14 Iron Age cemeteries with hiisi sites. Cup-marked stones, sacred trees and springs which have been found in the vicinity of these hiisi sites also seem to imply a connection between cemeteries and cult locations or sacred places. This connection, however, is debatable because there is nothing in these cemeteries that distinguishes these from other cemeteries of the period. Even the grave objects are by no means unique. The questions thus remain: What does the word 'hiisi' mean? Is it always possible to associate the hiisi sites with death and ancestor worship or could there be other explanations regarding their function?
\end{abstract}

Key words: cemeteries, Finland, hiisi/Hiisi, Iron Age, Mauno Koski, place names, sacred groves

\section{INTRODUCTION}

According to the Finnish linguist Mauno Koski, the Finnish word hiisi stands for a cult location or place were the dead and the spirits of ancestors were worshipped (Koski 1967: 81, 225, Koski 1990: 409, 432). Finnish hiisi sites are often described as stony places situated on top of steep mountains or small moraines, not far from Iron Age cemeteries. They are also said to be situated close to the water (Koski 1967: 196, 201). This description nicely corresponds to the locations of Iron Age cemeteries in Finland. Therefore, archaeologists have suggested that there might be a connection between cultic places and cemeteries, especially in western Finland (Huurre 1990: 209, Hirviluoto 1992).

In archaeological literature, the word hiisi is often explained only cursorily as a pre-Christian sacred grove or sacrificial site, and it is thus in accordance with the ideas of Mauno Koski. The negative connotations that are attached to the word have probably developed later, in Christian times. Thus the word that once marked a place gradually became to signify a being (Tallgren 1933, Koski 1967, Anttonen 1996). Namely, in Finnish folklore, the inhabitants of 
hiisi were often explained as supernatural beings that were either big and strong or small and deceitful. It was believed that these beings lived in a mythical time, long ago, together with giants and trolls. According to folkloric material, people believed that the hiisi beings had built the Bronze Age cairns (Killinen 1885: 135-137, Maajoki 1939, Huurre 1964).

In his doctoral thesis from 1967, Mauno Koski presented a list of Iron Age cemeteries in Finland which place name contained the word 'hiisi'. In the thesis he mentions 14 sites, ${ }^{1}$ mostly from the former provinces of Finland Proper, Satakunta and Häme in SW-Finland (Koski 1967).

However, Koski was not the first to make a list of possible hiisi sites. The Finnish archaeologist Aarne Michaël Tallgren wrote an article about Finnish hiisi sites already in 1933. Tallgren listed 15 or 16 possible hiisi sites, ${ }^{2}$ all of which are located in Finland Proper. He believed that these sites had been in use already during pre-Christian times. Even though Tallgren noticed a link between the hiisi sites and Iron Age cemeteries, he never attempted to associate these directly and merely mentions the place names that are connected to the word hiisi (Tallgren 1933).

Not much is known about what happened at these hiisi sites and when exactly they were in use. A hiisi site is typically described quite vaguely as a cultic place which is situated on top of a stony hill or mountain. Evidently, the name hiisi often appears in a place name together with the compound - mäki ('hill' in Finnish) to mark these places (Finnish: Hiisimäki / Hiidenmäki). In addition, the hiisi sites are linked to the cult of the dead because, as mentioned in the thesis by Koski, cemeteries can be often found on top of hiisi hills. But do these cemeteries differ in any way from other cemeteries of the period? Why the toponyms containing the word hiisi do not appear more frequently in the names of Iron Age cemeteries in Finland? Is there perhaps something unique in the topography or in the nature of grave goods?

People have the ability to become attached to certain places on the landscape through their memories and feelings. In the course of time, certain places, such as moraines, may acquire deeper meanings. The love of or the respect towards a place can thus result in its being used time and time again and the place thus becomes layered with feelings (Tuan 1974). Mauno Koski, however, views the cultic places and cemeteries as coexistent but he does not ask why certain sites have become cultic places while others have not. Nor does he define more precisely what he means by a cultic place (Koski 1967). Was there, for example, something special in the landscape features of these sites which made them suitable for being chosen as cultic places? Can archaeological methods be useful in solving these questions? Since the ideas of Mauno Koski have 
received so much attention throughout the years, especially among archaeologists, his list of hiisi sites is presented below.

\section{OVERVIEW OF THE MATERIAL}

The hiisi sites which have been mentioned in Koski's thesis have actually many things in common. All of them are situated on top of stony moraines or promontories, thus following the topographical characteristics of a hiisi site as described in the thesis. They are also frequently found close to rivers ${ }^{3}$ or lakes ${ }^{4}$. The topography and the proximity to water are also significant features of Iron Age cemeteries in Finland, so these two characteristics apply both to the hiisi sites and the cemeteries.

It seems that the place names containing the word hiisi are quite old because they occasionally appear in old maps. The Märttelä Hiisimäki site in Rusko, for example, is mentioned in a 14th-century document, referring to a farm called Hiidenvainio, which stands for 'the hiisi field' (Tallgren 1919: 11).

Kaisela Hiidenmäki in Nousiainen appears on a map from the 1780 s. Possibly, there have been other hiisi sites in Nousiainen: for example, the local chaplain Jaakko Alleén mentions in his diary from 1736-1768 a meadow called Hiidenmäenveräjänloukas and a hillock called Hiidenkankare (Oja 1977: 2527).

Other names, such as Hiitteennokka, Kuparinokka and Vaskiniemi, have been connected to the hiisi site of Narva Hiidennokka in Vesilahti municipality. All these names are probably associated with folkloric accounts about treasures hidden on this promontory. According to old 19th-century maps there are many place names containing the word hiisi in the area surrounding Hiidennokka, such as Hiisi, Hiidenmoisio, Valtia, and Hiidenlahti (Arajärvi 1950: 16, 31). According to Kirsti Arajärvi this phenomenon might suggest that Hiidennokka functioned as a village cultic place. After all, in 1540 Narva was the largest village in Vesilahti with 16 farms (Arajärvi 1950: 31, 130-132).

There is an often-cited written document from 1229 written by Pope Gregory IX (1227-1241) which promises to give all the Finnish sacred pagan groves to the church, "luci et delubra, deputati olim ritibus paganorum". This document declares that the church, in fact, does not claim this land for itself by force but instead the Finns give these sacred places to the church "voluntate spontanea", voluntarily and spontaneously (Tallgren 1933: 327). It is evident that the church would have interpreted these land donations as a voluntary and peaceful act; the perception of the local people, of course, would be quite another matter. As 
it turned out, some of the hiisi sites that were mentioned in the thesis of Mauno Koski are in fact situated on the church land. ${ }^{5}$ The Kylähiisi (Finnish: 'hiisi village') site in Uusikaupunki is said to have belonged to the local presbytery already in 1411 (Huurre 1964, Koski 1967). According to the archaeologist Matti Huurre, the Pyhäkoski waterfall (Finnish: 'holy falls') nearby could also be related to the sacrality of this place (Huurre 1964). Kaninkola Hiisimäki in Halikko is mentioned already in the 14th-century written sources as a meadow which belonged to the church (Koski 1967: 124).

There is additional evidence at some hiisi sites which may confirm that the hiisi sites are actual cultic places. According to Mauno Koski there probably was a sacred rowan tree in the village of Kylähiisi in Uusikaupunki (Koski 1967: 121). Over 16 Iron Age cemeteries were reported to belong to the Kylähiisi village together with a large erratic boulder with 13 cup-marks (Huurre 1964). Another cup-marked stone is known from Hiisimäki in Nousiainen (Laukkanen 2003). In Hiidennokka in Vesilahti there is a sacred spring which was used, according to a local man Kalle Lastunen (born in 1884), for healing practices (Maajoki 1939).

Already the list of pagan gods in the preface of the Finnish translation of the Psalms (Psalter) by Mikael Agricola mentions that people have worshipped many other things, such as stones, stumps (of old sacred trees?), the stars and the moon: "Palueltin mös palio mwta, Kivet, Cannot, Tädhet ia Cwta" (Agricola 1551). Cup-marked stones or rock outcrops are quite often found in connection with cemeteries. Actually, one third of the known Finnish cup-marked stones are found either in Iron Age cemeteries or their immediate vicinity. This is especially true for Finland Proper and Häme regions in the period between the Roman Iron Age and the Crusades. Another significant feature is that they are located in the surroundings of old farmlands. Their presence might suggest that the original function of the cup-marks was associated with the cult of the dead, and thus with fertility (Äyräpää 1941: 180-182, Edgren 1993: 253).

Nearly all the hiisi sites mentioned in Koski's thesis are cemeteries dating back to the Iron Age. Only one of them is an inhumation cemetery (Hiisiniemi in Köyliö), but unfortunately it has not been dated more precisely and thus could be dated to any period between the Merovingian period and the historical times (Salo 1953). The rest of the mentioned hiisi places are cremations in either earth-mixed cairns or cremation cemeteries below the level ground dated from the Roman period to the Viking Age. 


\section{FOLKLORE}

Oral lore about hiisi sites is mostly connected with the inhabitants of the hiisi (trolls or giants) rather than with rituals performed there. It thus seems that the folklore dates to a much later period and not to the time when the hiisi sites were used as cult locations (Koski 1967). Most folklore narratives describe how hiisi sites were inhabited by creatures and present origin myths associated with them; for example, how certain adjacent rock formations were created. Some stories tell about hidden treasures (Maajoki 1939, Salo 1953).

It seems that many hiisi sites have been in use also in later times, even though it is possible that the meaning of these sites had already changed by then. Oral tradition reveals that the young people of the village gathered in the hills to light bonfires on special holidays such as on Whitsunday or Midsummer Eve (Maajoki 1939, Vuorinen 1996, Salminen 1905: 3, Koski 1967: 171-172, Sarasmo 1946).

Most of the recorded folklore comes from a single place - the village of Narva in the municipality of Vesilahti. Väinö Maajoki, who carried out an archaeological survey in Vesilahti in 1939, also recorded local folklore, which is in fact quite rare in Finnish archaeological reports.

Most of the folklore collected from Vesilahti concerned the Hiidennokka site in Narva village. According to a legend, there is a hidden treasure on the cape of Hiidennokka. Local people reported having seen a copper cauldron filled with coins rolling down the cliffs and then being caught in the nets of a local fisherman.

Narvan Hiidennokassa on nähty kuparikattilan täynnä rahaa vierivän rinnettä alas. Eräs kalastaja oli saanut pyydykseensä rahaa täynnä olevan kattilan Hiidennokan luona. (Kaarlo Laaksovirta, born in 1892, Jokioinen village.)

[On Hiidennokka Point in Narva, a copper kettle was seen rolling down the hill. A fisherman caught a kettle full of money in his net near Hiidennokka. (Translated by Jarmo Kankaanpää.)]

There could be some truth to this story. There are several visible cairns on the cape that might have drawn the attention of local inhabitants. It is also a wellknown fact that throughout the ages people have looted cemeteries in search of treasures (Ailio 1928, Taavitsainen 1990: 44-45). However, bronze cauldrons filled with coins were quite unusual at this time, and the account may thus refer to later treasures, such as those from the 18th-century Great Northern War. 
Several narratives are also connected with the legend of the origin of Cape Hiidennokka. According to these accounts, giants threw big rocks into the lake but were stopped by another giant who did not want the rocks to block the boat route. Another story relates how the giants did not like the people from Narva village passing the inlet in their boats on their way to church and blocked the boat route to prevent this.

Kerran jättiläiset heittelivät Vuorenmaan takaa Narvan seuratalon takaa kiviä Hiidenokan ja Karholannokan väliseen salmeen. Havulinnan talon takana asuva jättiläinen esti tämän, koska ei halunut, että veneväylä tukkeentuisi. Toisen tarinan mukaan Jantin palvelijatar näki jättiläisten työn ja huusi siitä muille. Yllätettyinä jättiläiset jättivät työnsä kesken. (Kalle Lastunen, born in 1884, Narva village.)

[Once the giants were throwing stones from behind Vuorenmaa behind Narva community hall into the strait between Point Hiidennokka and Point Karholannokka. The giant living behind Havulinna Farm halted this, because he didn't want the channel to be blocked. According to another story, a maid at Jantti Farm saw the giants at work and yelled to the others about what was going on. Surprised, the giants left their work unfinished. (Translated by Jarmo Kankaanpää.)]

Jättiläiset heittivät kiviä veteen tehdäkseen sillan Hiidennokasta Karholannokkaan. Täten syntyi salmen poikki kivirivi VainionnokkakiviSatulakivi - Tuomaankivi ja Tulikarikivi, joita pitkin harppaamalla jättiläiset pääsivät salmen yli. (Silen, birth date unknown, Narva village.)

[The giants threw stones into the water in order to make a bridge from Hiidennokka Point to Karholannokka Point. This was the origin of the row of stones that crosses the sound, Vainionnokkakivi - Satulakivi Tuomaankivi and Tulikarikivi, which the giants used as stepping stones to get across. (Translated by Jarmo Kankaanpää.)]

Hiidennokassa asui ennen jättiläisiä. Nämä eivät pitäneet siitä, että narvalaiset kävivät kirkossa. Estääkseen tämän he yrittivät kivillä sulkea salmen Hiidennoka ja Karholannokan välillä, jotta narvalaisten kirkkoveneet pääsisi siitä läpi. (Juho Lehtonen, born in 1867, Sakoinen.)

[Hiidennokka Point used to be inhabited by giants. They didn't like the Narva folks going to church. To put a a stop to it, they tried to block the 
channel between Hiidennokka Point and Karholannokka Point, so that the church boats of the Narva folks couldn't get through. (Translated by Jarmo Kankaanpää.)]

Similar lore has been recorded from Kylähiisi in Uusikaupunki. According to a story, a hiisi creature (a troll) inhabited the nearby Pyhäkoski hill. When other hiisi beings came to visit from the nearby village of Laitila, the village got its current name, Kylähiisi (Jalo Luukkala from Hallu farm, in Huurre 1964).

There is also a somewhat indecent story about the origin of Hiisiniemi ('Hiisi Point') at Yttilänotta in Köyliö:

Järven toisella puolella kynti akka härkäparin kans', kun hiisi toi helmassaan santaa ja kiviä, puoliksi kumpaakin. Silloin akka rupesi pilkkaamaan: Hiisi, Hiisi, ne näkyy! (Kun Hiiden helma oli ylhäällä). Hiisi suuttui ja pudotti helmastansa maan ja kivet, jolloin syntyi Yttilänotta. Hiisi otti samalla suuren kiven, jolla heitti akkaa. Tämä jäi härkineen sen alle. Kivi on nykyisin rikottuna Kepolan kartanon navetassa. (August Vähätalo in Salo 1953.)

[There was a woman ploughing wi' a pair of oxen on the other side of the lake, when the Hiisi [troll] brought sand and stones in his lap, half of each. The woman began to taunt: Hiisi, I can see them! (Because the Hiisi had his shirt hem up). The Hiisi lost his temper and dropped the earth and stones, and they formed Yttilänotta. Then the Hiisi took a big stone and threw it at the woman, and she was caught under it with her oxen. The stone is now broken into pieces and forms part of the cow barn wall at Kepola Manor. (Translated by Jarmo Kankaanpää.)]

\section{CEMETERIES AS CULTIC PLACES - A DISCUSSION}

The striking feature in the list of Mauno Koski's hiisi sites is that they all have certain aspects in common. All the 14 sites are found on top of elevations, such as stony moraines or on top of rock promontories. Thus they are all visible or prominent in the surrounding landscape. All these places have the word 'hiisi' in their names. Sometimes folklore has been recorded in these places, but it is mostly connected with the origin of the places rather than the ritual practices. Also, archaeological finds have been discovered in these places. The following passage seeks to answer the questions such as: Could the cemeteries be of more recent origin? Is it possible that a sacred place was there first and the 
cemeteries were constructed on these sites because these places were sacred or holy? Is it in fact the natural places that were of primary importance for the cultic activities and the cemeteries were only secondary? If so, is there any archaeological evidence to support this idea?

Archaeological finds are often seen as the evidence of a preformed cult but an observation of the find material from the 14 sites revealed nothing special. It has proved difficult to determine which artefact types were of sacred character and which were not. In terms of grave goods, the finds do not differ in any way from those found in other cemeteries. In fact, it is difficult to determine if any of the finds date back to the period when the place of worship was in use or if perhaps the activity attested by archaeological findings occurred much later. For example, is it possible that the Iron Age cemeteries were built at the sites of the cultic places much later, perhaps because the hills were still believed to be sacred or because legends were attached to them? At the same time, if the word 'hiisi' originally designated a cultic place where dead ancestors were worshipped then perhaps the idea of looking for a cemetery at the place of former hiisi sites is not so farfetched? This leads to several additional questions: How were the dead ancestors worshipped? Were food and drink offered to them, because animal bones and ceramics have been found in great numbers at these sites? Were only rituals with songs and dances performed there, of which no archaeological traces were left?

If some cemeteries indeed functioned as cultic places or hiisi sites during the Iron Age, then are there any material remains to support this idea? Certain find categories, such as burned clay, daub, unburned animal bones and teeth or iron slag are sometimes seen as having ritual character but at the same time they are also difficult to date and define. Is it possible that these find categories originate in a later settlement activity or are they remains of performed rituals? Often these remains have been given a functionalistic interpretation in the archaeological literature in Finland, such as deriving from an older settlement site layer, smithy site, or being the remains of a funeral pyre (Europaeus 1914: 37-39, Meinander 1943: 45-46, Taavitsainen 1992: 712, Hirviluoto 1996: 79, Purhonen 1996: 121, Svarvar 2002: 127, 149). However, these remains can also be evidence of commemoration rituals, ancestral cult and even cult houses (Kaliff 1992: 93-98, Shepherd 1997: 14-17, Svarvar 2002: 127, 147-149, Pietikäinen 2006: 96, cf. Tegengren 1934).

The remains of smithy activity found on the sites of many cemeteries could be suggestive of fertility ideas and are thus symbolic rather than functional. Forging is a transformative process that symbolically represented giving birth to iron objects (Gansum 2004, Burström 1990). This could explain why traces 
of forging and its by-product slag are so often found in connection with cremation cemeteries.

The fine and coarse types of pottery which have been often found in cremation cemeteries tell of different kinds of death rituals. The fine ware can probably be associated with funerary rituals while the coarse ware can be associated with food offering in commemoration rituals. Especially the items of pottery that have been found in cemeteries near the ground surface have traditionally been explained as sacrificial objects and associated with commemorative rituals (Aroalho 1978: 67, Hirviluoto 1996: 78-79).

The traces of ritual activity suggest that the cemeteries had different functions at different times of the year. They had a much more pluralistic purpose and should not be merely studied as places for disposing the dead. Cemeteries could have functioned as small-scale communal ritual centres and as meeting places where the whole community performed their rituals also between funerals (cf. Anttonen 1996: 116, Purhonen 1996).

\section{HIISI: THE GOD OF THE FOREST AND THE FUR?}

A popular way of studying prehistoric worship and beliefs in Finland has traditionally been to study the list of pagan gods by Bishop Mikael Agricola (15101557). This list is found in the preface to his Finnish translation of the Psalms (Psalter). The text is written in verse and it mentions both the gods of Häme and Karelia. Many of these names can also be found in the Finnish national epic Kalevala (e.g., Tapio, Ahti, Väinämöinen, Ukko, Ilmarinen). However, it is important to use source criticism while using this list because Agricola's intention was to contend paganism in the spirit of the Reformation. Later scholars have thus suggested that a considerable number of Agricola's gods are in fact local guardian spirits, Christian saints, and names for the deceased. Elias Lönnrot was, for example, critical of Agricola's use of folklore and proposed that some of his deities were in fact heroes like those mentioned in the Kalevala. In his text Agricola names two gods who rule over the forest and hunters. Tapio is the god who brings home the game from the forest: "Tapio, Metzest Pydhyxet soi". Hiisi is described as another god that "Metzeleist soi woiton", which either means that it is Hiisi who brings catch from the forest (fur?) or that it is the god of big wild game (Agricola 1551, Pentikäinen 1999: 7-8, Siikala 1992: 140).

In an article published in 1954, the Finnish historian Gunvor Kerkkonen speculated that in southern Finland, hiisi sites may have functioned as storing 
centres of international fur trade. Kerkkonen relies in her argument on the fact that most of the hiisi sites in this area are situated either in river valleys, and thus close to important water routes, or directly on the coast, and also on the fact that some of the hiisi place names in SW-Finland are mentioned in written documents already in the 14th and 15th century (Kerkkonen 1954: 89). At the same time, most of the Iron Age cemeteries, especially in SW-Finland, are situated in river valleys, and associating this fact only with fur trade is somewhat misleading. In addition, it sounds strange that Kerkkonen has suggested that a cultic place which would naturally be sacred in nature would function as fur storage and has thus merged the economic and the religious spheres, without providing any argument to support her ideas.

Of all the find material discovered at the hiisi sites mentioned by Mauno Koski, artefacts that could be directly related to trading activity were found from only one cemetery: the scales with eight weights inside a bronze container were found in Märttelä Hiisimäki in Rusko, SW-Finland. These artefacts were found, together with a spearhead, next to a large stone in 1918 (Huurre 1962). The site attracted the attention of excavator Aarne Michaël Tallgren, because the place name contained the word 'hiisi' and the name appeared on a 14th-century map. Tallgren (1919: 11) suggested that the finds were discovered in a cache and not from a cemetery but according to the database of prehistoric sites available by the National Board of Antiquities in Finland, the site has later been interpreted as a cremation cemetery below the level ground.

In her article, Gunvor Kerkkonen pointed out that the island of Hiittinen (Swedish: Hitis) in the archipelago of SW-Finland may have been a trading place due to its favourable location between the east and the west (Kerkkonen 1954: 89). Ironically, several decades later researchers actually found a trading place and a possible hiisi site on the same island. The Kyrksundet site includes the ruins of a medieval chapel with a cemetery dating back to 1400-1500 AD and a Viking Age trading place connected with a harbour (Edgren 1995, 1999: 9). The Viking Age finds can be clearly linked to trade activities, as they include fragments of Arabic silver coins, dozens of weights, and keys originating in Gotland. There are also traces of bronze jewellery manufacture, even though no actual buildings or other constructions could be connected with the trading place (Edgren 1995: 208-209). Torsten Edgren has concluded that Kyrksundet has been the most important trading centre in the Finnish area, situating along the eastern route of the Vikings (Edgren 2000: 106).

Large erratic boulders are situated on the highest peak of the trading place. The oldest finds were discovered in this site during excavations carried out in 
1994 and 1995. In 1994 a round bronze brooch and some bronze spirals were found between two large stones. Eight meters from this find, a sword blade and a spearhead, both dating back to the Viking Age, were discovered. In 1995 a pommel with silver ornaments from a type "H" sword were found, together with a grip and a guard, stuck between two stones. None of these finds could be associated with the cemetery and, according to the excavator Torsten Edgren, they cannot be connected to the trading place either. Edgren (1999: 11-15) interpreted the finds as sacrificial objects. He considered the place name Hiittinen/Hitis as an indication of the sacral nature of this place and thus associated the place with ancestral cult. The place name Hijttisbij, marking the village of Hiittinen, and appeared for the first time already in 1540 (Edgren 1995: 10, 15-17).

An important aspect in the Kyrksundet material is represented by the ruins of a medieval chapel, which is situated only 300 meters from the site interpreted as the cultic place (Edgren 1999: 11-15). The place name Hijttisbij suggests that the place was in use around the same time than the chapel was used. Could this be an indication of the fact that the church had claimed this land for itself or had got the land from the people as has been stated in the document by Pope Gregory IX, because there had indeed been a cultic place before?

\section{CONCLUSION}

This article presents an overview of Finland cemeteries which name contains the word 'hiisi'. Evidently, not much evidence is needed to name a place hiisi; the toponym and the existence of a cemetery seem to be enough. The word 'hiisi' thus seems to be a general name for places with ritual character and is thus perceived as synonymous with cultic places. If we look at the above-cited text by Mikael Agricola, hiisi or Hiisi has nothing to do with the cult of the dead but is instead some sort of a spirit or god who rules over the forest and the animals. It is possible that the meaning of the word had changed by the time he wrote his list of pagan gods.

The cultic places seem to be linked to cremation cemeteries by topography since both are often found on top of small and stony hills, often with large erratic boulders. In later periods, these places have quite often functioned as meeting places, suggesting that they might have been important places over a long time. As it is so often the case with Iron Age cemeteries, these places are 
also frequently found to be connected with water. In addition, there are historical documents that link some hiisi sites to the church.

If the church was in fact trying to claim ownership over the old hiisi sites, then is the church also to blame for the negative folklore that is often connected with these sites? This would have been a good strategy which aim was to make the old sacred sites frightening for the people. On the one hand, if the hiisi sites were still in use when the church took them into its possession, then probably it would not have been so easy. On the other hand, if the sites had already become abandoned by that time, these would not have been too significant for the people and they voluntarily gave these over to the church. Christianity was introduced in Finland during early medieval times. The cemeteries in Koski's list are all dated to the period between 300-1000 AD, suggesting that they were perhaps already forgotten by the time the church took the land into its possession.

It is evident that the meaning of the word ' $h$ iisi' is not clear: sometimes it is indicative of the cult of the dead and at other times it has a vaguer meaning, denoting some sort of a negative being. We should probably approach the word with more care.

\section{ACKNOWLEDGMENTS}

The author wishes to thank the two anonymous referees and the editors for the valuable comments which helped to improve this article, and the Finnish Cultural Foundation for its financial support. I am grateful to Jarmo Kankaanpää, PHD for translating parts of this text into English.

\section{NOTES}

1 (1) Kylähiisi in (former Kalanti) Uusikaupunki, (2) Kaninkola Hiisimäki in Halikko, (3) Forsby Hiisi in Kokemäki, (4) Napue Hiisimäki in Isokyrö, (5) Loimaa Hiidentöykkä in Huittinen, (6) Narva Hiisi in Vesilahti, (7) Vuoltee Hiisi in Kokemäki, (8) Yttilä Hiidenniemi in Köyliö, (9) Kaisela Hiisimäki in Nousiainen, (10) Kallela Hiidenvainio in (former Kalanti) Uusikaupunki, (11) Ryssä Hiisimäki in (former Tyrvää) Vammala, (12) Kutala Hiidenvainio in (former Karkku) Vammala, (13) Sillantaa Hiittiänmäki in (former Sääksmäki) in Valkeakoski, and (14) Märttelä Hiisimäki in Rusko (Koski 1967: 173).

2 (1) Kaninkola Hiisimäki and Pintilä Hiidenmäki in Halikko, (2) Sauvala Hiisi in Lieto, (3) Kodisjoki Hiitteenvuori and Vanhantaka Hiittiönjärvi in Laitila, (4) Kurittula Hijvuori in Masku, (5) Hiittiönmäki and Hiitteenkirkko in Mynämäki-Mietoi- 
nen, (6) Sontamala Hiito in Nousiainen, (7) Hiidenala/Hirnala in Paimio, (8) Sydänsauru Hiiro in Perniö, (9) Hiirometsä: Isohiisi, Vähähiisi and Nokkahiisi in Pertteli, (10) Piikkiö Hiisi, (11) Märttelä Hiisimäki and Hiidenvainio in Rusko, (12) Hiidenmetsä in Sauvo, (13) Hiitteenvainio and Kylähiisi in Uusikaupunki, (14) Kärsämäki Hiisi in Turku, (15) Hiirenmäki in Vehmaa. Tallgren also suggested that the island of Hiittinen (Swedish: Hitis) in the southwestern archipelago could have functioned as a cultic place for hunters coming from far away. (Tallgren 1933: 322-328)

${ }^{3}$ E.g., Kylähiisi in Uusikaupunki, Hiisimäki in Halliko, Hiidentöykkä in Huittinen, Hiidenmäki in Vammala, and the Forsby and Vuoltee hiisi sites in Kokemäki.

4 Hiidennokka in Vesilahti, and Hiisiniemi in Köyliö.

5 Hiisimäki in Nousiainen, Kaninkola Hiisimäki in Halikko, and Kylähiisi in Uusikaupunki.

\section{REFERENCES}

Ailio, Julius 1928. Hattelmalan rautakautinen kätkölöytö. [The Iron Age Hoard Find from Hattelmala.] Suomen Museo 1928, pp. 51-54.

Agricola, Mikael 1551. Alcupuhe Psaltarin päle. Virtuaalinen Vanha Kirjasuomi-database (VVKS). Available at http://www.vvks.info/tekstit/1500_1_agricola/3b/, last accessed on 21 July 2009.

Anttonen, Veikko 1996. Ihmisen ja maan rajat. "Pyhä" kulttuurisena kategoriana. [Corporeal and Territorial Boundaries. The Sacred as a Cultural Category.] Suomalaisen Kirjallisuuden Seuran Toimituksia, 646. Helsinki: Suomalaisen Kirjallisuuden Seura.

Arajärvi, Kirsti 1950. Vesilahden historia. [History of Vesilahti.] Tampere: Vesilahden seurakunta ja kunta.

Aroalho, Jouko 1978. Lieto-Haimionmäki. Nuoremman rautakauden polttokenttäkalmisto Aurajokilaaksossa. [Lieto-Haimionmäki. Early Iron Age Cremation Cemetery below the Level Ground in Aura River Basin.] Karhunhammas 2, No. 2. Turku: Turun yliopiston Moniste.

Burström, Mats 1990. Järnframställning och gravritual. En strukturalistisk tolkning av järnslagg i vikingatida gravar i Gästrikland. [Iron Production and Burial Ritual. A Structuralist Interpretation of Iron Slag in Viking Age Burials in Gästrikland.] Fornvännen. Vol. 85, pp. 261-270.

Edgren, Torsten 1993. Den förhistoriska tiden. [The Prehistoric Times.] In: T. Edgren \& L. Törnblom (eds.) Finlands Historia I. Ekenäs: Schildts.

Edgren, Torsten 1995. Saariston hiisi. [The Archipelago Hiisi.] Hiidenkivi. Suomalainen kulttuurilehti. Vol. 1 (1995), pp. 10-16.

Edgren, Torsten 1999. Fornlämningar och fornfynd i Hitis utskär. [Ancient Sites and Ancient Finds from the Outer Islands of Hitis.] Offprint in the Library of the National Board of Antiquities in Helsinki, Finland. 
Edgren, Torsten 2000. The Eastern Route: Finland in the Viking Age. In: W.W. Fitzhugh \& E. I. Ward (eds.) Vikings. The North Atlantic Saga. Washington: Smithsonian Institution Press, pp. 103-115.

Europaeus, Aarne 1914. Gravfynd i Uskela. [Burial Finds from Uskela.] Finskt Museum 1914, pp. 23-38.

Gansum, Terje 2004. Role of the Bones - From Iron to Steel. Norwegian Archaeological Review. Vol. 37, No. 1, pp. 41-57.

Hirviluoto, Anna-Liisa 1992. Ett gravfynd från järnåldern på Hiisimäki i Halikko. [A Burial from Iron Age at Hiisimäki in Halikko.] Finskt Museum 1992, pp. 11-20.

Hirviluoto, Anna-Liisa 1996. Pottery, Burnt Clay and Slag. In: P. Purhonen (ed.) Vainionmäki - A Merovingian Period Cemetery in Laitila, Finland. Helsinki: The National Board of Antiquities, pp. 73-80.

Huurre, Matti 1962. Ruskon inventointi. [The Survey of Rusko.] Unpublished survey report. The Archives of the National Board of Antiquities, Finland.

Huurre, Matti 1964. Kalanti. Inventointikertomus. [Survey Report of Kalanti.] Unpublished survey report. The Archives of the National Board of Antiquities, Finland.

Huurre, Matti 1990. 9000 vuotta Suomen esihistoriaa. [9,000 Years of Finnish Prehistory.] Helsinki: Otava.

Kaliff, Anders 1992. Brandgravskick och föreställningsvärld. En religionarkeologisk discussion. [Cremation Burial Practices and Religious Beliefs. A Religio-Archaeological Discussion.] Uppsala: Societas Archaeologica Upsaliensis.

Kerkkonen, Gunvor 1954. Hiisi-asutukset Etelä-Suomen turkiskaupan tapulipaikkoina. [Hiisi Sites as Staple Places for Fur Trade in Southern Finland.] Kalevalaseuran vuosikirja. Vol. 34, pp. 87-100.

Killinen, Kustaa 1885. Muinaisjäännöksiä Vehmaan kihlakunnassa. [Ancient Sites in Vehmaa Parish.] Suomen Muinaismuistoyhdistyksen Aikakauskirja VII, pp. 139-140.

Koskenheimo, Jukka 2000. Jättiläisten jälkiä. [Traces of the Giants.] Helsingin Sanomat, Kulttuuri (11.07.2000).

Koski, Mauno 1967. Itämerensuomalaisten kielten hiisi-sanue. Semanttinen tutkimus I. [The Word Hiis in Baltic-Finnic Languages. Semantic Study, 1.] Turku: Annales Universitatis Turkuensis.

Koski, Mauno 1990. A Finnic Holy Word and Its Subsequent History. In: T. Ahlbäck (ed.) Old Norse and Finnish Religions and Cultic Place Names. Conference Proceedings. Based on papers read at the Symposium on Encounters between Religions in Old Nordic Times and on Cultic Place Names held in Åbo, Finland, on the 19th-21st of August, 1987. Åbo: The Donner Institute for Research in Religious and Cultural History, pp. 404-440.

Laukkanen, Esa 2003. Nousiasten esihistorialliset löydökset sekä hajatietoja historiallisen ajan kohteista. [Prehistoric Finds from Nousiainen and Scattered Information about the Sites Dated to Historic Times.] Unpublished survey report. The Archives of the National Board of Antiquities, Finland.

Maajoki, Väinö 1939. Luettelo Vesilahden pitäjän kiinteistä muinaisjäännöksistä. [Catalogue over the Ancient Sites in Vesilahti Parish.] Unpublished manuscript. The Archives of the National Board of Antiquities, Finland. 
Meinander, Carl Fredrik 1943. Några forngravar från Laihela. [Some Ancient Burials from Laihela.] Finskt Museum L, pp. 32-46.

Oja, Aulis 1977. Nousiaisten historia I. [The History of Nousiainen.] Nousiaisten kunta \& Nousiaisten seurakunta: Turun Sanomat.

Pentikäinen, Juha Y. 1999. Kalevala Mythology. Expanded edition. Translated and edited by Ritva Poom. Bloomington: Indiana University Press.

Pietikäinen, Taina 2006. Muutos ja pysyvyys - hautausrituaali nuoremmalla rautakaudella Raision Mahittulan Tuomalan kalmistossa. [Change and Stability Burial Ritual in the Mahittula Tuomala Cemetery in Raisio during Late Iron Age.] Unpublished MA thesis. Turku: University of Turku, Dept. of Cultural Studies, Archaeology.

Purhonen, Paula 1996. Mortuary Practices, Religion and Society. In: P. Purhonen (ed.) Vainionmäki-A Merovingian Period Cemetery in Laitila, Finland. Helsinki: The National Board of Antiquities, pp. 119-130.

Salminen, Viktor 1905. Köyliön pitäjän historia. Pitäjänkertomuksia VII. [The History of Köyliö Parish. Parish Stories, 7.] Suomalaisen Kirjallisuuden Seuran Toimituksia, 47. Helsinki: Suomalaisen Kirjallisuuden Seura.

Salo, Unto 1953. Köyliön pitäjän kiinteät muinaisjäännökset. [Ancient Sites in Köyliö Parish.] Unpublished survey report. The Archives of the National Board of Antiquities, Finland.

Sarasmo, Esko 1946. Kokemäen kiinteät muinaisjäännökset. [Ancient Sites in Kokemäki.] Unpublished survey report. The Archives of the National Board of Antiquities, Finland.

Shepherd, Deborah J. 1997. The Ritual Significance of Slag in Finnish Iron Age Burials. Fennoscandia Archaeologica. Vol. 14, pp. 13-22.

Siikala, Anna-Leena 1992. Suomalainen šamanismi. Mielikuvien historiaa. [Finnish Shamanism. History of Ideas.] Suomalaisen Kirjallisuuden Seuran Toimituksia, 565. Hämeenlinna: Suomalaisen Kirjallisuuden Seura.

Svarvar, Kjell 2002. Brandgravfältet vid Pörnullbacken. Tolkningar av gravskick och gravritual. [The Cremation Cemetery in Pörnullbacken. Interpretation of Burial Customs and Rituals.] In: K. Viklund \& K. Gullberg (eds.) Från romartid till vikingatid. Vasa: Scriptum, pp. 121-158.

Taavitsainen, Jussi-Pekka 1990. Ancient Hillforts of Finland. Problems of Analysis, Chronology and Interpretation with Special Reference to the Hillfort of Kuhmoinen. Suomen Muinaismuistoyhdistyksen Aikakauskirja, No. 94.

Taavitsainen, Jussi-Pekka 1992. Cemeteries or Refuse Heaps? Suomen Museo 1991, pp. 5-14.

Tallgren, Aarne Michaël 1919. Nya fornfynd och fasta fornlämningar. [New Finds and Ancient Sites.] Finskt Museum 1919, pp. 11-16.

Tallgren, Aarne Michaël 1933. Hiisi ja Moisio. Virittäjä. Kotikielen Seuran Aikakauslehti. No. 37, pp. 319-331.

Tegengren, Jacob 1934. Ett litet bidrag till frågan om likbränning i hus. Excavationes et studia opuscula in honorem Alfred Hackman 14.10.1934. [A Small Contribution to the Issue of Cremation Inside Houses.] Suomen Muinaismuistoyhdistyksen Aikakauskirja, No. 40, pp. 128-137. 
Tuan, Yi-Fu 1974. Topophilia: A Study of Environmental Perception, Attitudes, and Values. Englewood Cliffs, NJ: Prentice-Hall Inc.

Vuorinen, Juha-Matti 1996. Vesilahti. Arkeologinen inventointi 22.5.-14.6.1995. [Archaeological Survey of Vesilahti 22 May - 14 June 1995.] Unpublished survey report. The Archives of the National Board of Antiquities, Finland.

Äyräpää, Aarne 1941. Uhrikivi - kipujenkivi. [Offering Stones - Stones of Pain.] Kalevalaseuran vuosikirja. Vol. 22, pp. 179-208. 